\title{
Continuous-flow automation of the Lactobacillus casei serum folate assay
}

\author{
G. B. TENNANT
}

From the Department of Haematology, Welsh National School of Medicine, Heath Park, Cardiff CF4 4XN, UK

SUMMARY A method is described for the continuous-flow automation of the serum folate assay $\dot{\omega}^{\circ}$ using Lactobacillus casei. The total incubation period is approximately four hours. The growth- $\vec{N}$ response of the organism to folate is estimated by measuring the rate of reduction of $2,3,5$-tri- $\vec{\overrightarrow{ }}$ phenyl tetrazolium chloride (TTC). A simple continuous culture apparatus is used to grow the $\mathscr{D}_{\infty}$ inoculum. Supplementation of the assay medium is necessary to obtain parallel results. A statistical 은 assessment shows a favourable comparison with the whole-serum tube assay using a chloramphenicol $\vec{D}$ resistant strain of $L$. casei. The method is less sensitive to inhibitory substances than the tube assay.

The routine assay of serum folate using Lactobacillus case is widely performed. Continual evolution of the assay has reduced the manual manipulation involved. Extraction procedures (Baker et al., 1959; Waters and Mollin, 1961) were simplified by assaying the whole-serum, initially 'aseptically' (Herbert, 1964, 1966; Harper, 1965) and later using chloramphenicol-resistant strains of $L$. casei (Davis et al., 1970). The use of chloramphenicol expedited the introduction of mechanical dilution of samples into seeded medium with simple diluters (Davis et al., 1970; Tennant and Withey, 1972) or more sophisticated preparation units (Millbank et al., 1970).

Continuous-flow systems have been devised to dilute assays into test-tubes (Berg et al., 1975) as well as to measure the turbidity of test-tube cultures (Slade et al., 1974) but the 17-hour incubation period has posed an inherent problem in the complete automation of folate assays. Davis et al. (1970) attempted to overcome it by 'storing' the segmented culture stream in a coil which they incubated overnight before pumping the culture out through the colorimeter. An alternative approach has been to estimate the folate limited growthresponse by measuring the rate of tetrazolium reduction during a very much shorter incubation period (Tennant and Withey, 1974). A routine procedure using this approach is described and assessed in this paper.

Received for publication 30 May 1977

\section{Method}

OUTLINE (Fig. 1)

A continuous stream of assay medium was se⿳亠丷厂犬: mented with air and inoculated with $L$. casei from a simple continuous culture. Serum samples, or standard folic acid (PteGlu) solutions, were diluted into the stream and incubated in a $37^{\circ} \mathrm{C}$ incubator as $\stackrel{\mathbb{D}}{\triangle}$ the culture was pumped through a polythene tube $\overrightarrow{\vec{P}}$ for approximately three hours. The culture was then debubbled and resegmented with nitrogen, and 2,3,5-triphenyl tetrazolium chloride (TTC) solution was added before further incubation for one hour. The total culture absorbance at $500 \mathrm{~nm}$ was ? measured and recorded. Serum folate values were calculated graphically by comparison of sample peaks with a standard curve.

\section{INOCULUM}

\section{Strain}

The organism used was a chloramphenicol-resistant strain of $L$. casei subsp. rhamnosus NCIB 11295 (National Collection of Industrial Bacteria, Torry Research Station, Aberdeen AB9 8DG) derived c from NCTC 10302. Chloramphenicol-resistant forms of ex-ATCC 7469 strains (Tennant et al., 1974) proved unsatisfactory with this method. The atypical chloramphenicol resistance of NCIB 11295 was $\stackrel{?}{-}$ associated with the production of large capsules. This characteristic could be partially lost if static cultures were grown with medium chloramphenicol 


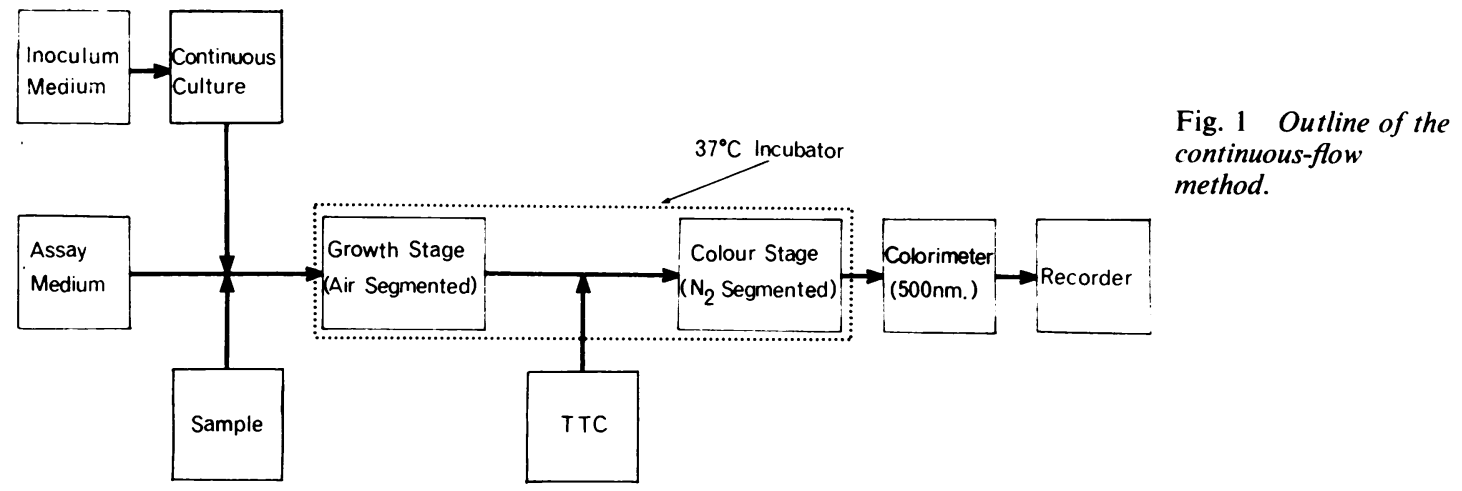

concentrations less than $100 \mathrm{mg} / \mathrm{l}$. Cultures were then unsuitable for use in this method.

\section{Relief staining of cells}

Capsules were demonstrated by a modification of the procedure of Butt et al. (1936). One loopful of the culture was mixed on a microscope slide with a similar volume of drawing ink (Rotring 6017). A thin film of the mixture was dried and then flooded with methyl alcohol containing methyl violet $(10 \mathrm{~g} / \mathrm{l})$. When dry, the films were washed in water and subsequently examined under an oil-immersion lens. The ink tended to precipitate if the culture $\mathrm{pH}$ was below $5 \cdot 0$

\section{Continuous culture (Fig. 2)}

The inoculum culture was grown in a simple chemostat $(220 \times 35 \mathrm{~mm})$ modified from Shaw and Duncombe (1963). Connections were made to $1 \mathrm{~mm}$ bore stainless-steel tubes (Fisons Scientific Apparatus Ltd, Loughborough LE11 0RG), pressed through the rubber bung, with $0.8 \mathrm{~mm}$ bore silicone rubber tube with $1.4 \mathrm{~mm}$ walls (Watson Marlow Ltd, Falmouth TR11 4RU). Rubber bungs to fit 1-litre medium reservoirs were fitted with a $1 \mathrm{~mm}$ bore connecting tube and a plugged vent-tube. A waterbath was maintained at $37^{\circ} \mathrm{C}$ by an aquarium heater and thermostat. A magnetic stirrer mixed both water and culture. Medium (Table 1) was made up weekly in 1-litre volumes and was pumped continuously by a delta-pump (Watson Marlow Ltd, model D/K40S) at a flow-rate of about $6 \mathrm{ml} /$ hour. (The flow-rate was monitored by timing the interval between successive drops from the inlet tube.) An overflow tube maintained the culture volume at $60 \mathrm{ml}$. As the growth-limiting substrate was folate its concentration in the culture supernatant was effectively zero (Herbert et al., 1956). The culture turbidity $\left(\mathrm{E} \begin{array}{c}1 \mathrm{~cm} \\ 560 \mathrm{~nm}\end{array}\right)$ was about $0 \cdot 5$
(pH $c 5 \cdot 10)$ and remained stable for up to six months.

\section{Establishing the continuous culture}

A freeze-dried culture was reconstituted and subcultured in MRS medium (Difco Laboratories Ltd, West Molesey KT8 OSE) (10 ml) containing chloramphenicol $(100 \mathrm{mg} / \mathrm{l})$ until a dense growth was obtained during overnight incubation at $37^{\circ} \mathrm{C}$. The continuous culture apparatus was prepared by autoclaving $\left(121^{\circ} \mathrm{C}\right.$ for 15 minutes) and the pumptubes by pumping $\mathrm{KOH}$ solution $(10 \mathrm{~g} / \mathrm{l})$ for about half an hour. The culture was set up by pouring the $10 \mathrm{ml}$ inoculating culture into the growth vessel which was then clamped into the water-bath and connected to the pump. Cultures took about 48 hours to equilibrate. Fresh medium was required at weekly intervals and was boiled before use. It was protected from direct daylight (Anderson and Cowan, 1968).

MANIFOLD AND FLOW CIRCUIT (Fig. 3)

The proportioning pump (Watson Marlow Ltd, model MHRE/22) was run continuously (except for 36 hours at the weekend) and pump-tubes were changed at weekly intervals. Small-bore pump-tubes (0.015-0.040 in) were anchored to modified Watson Marlow nipples made by breaking off one probe and gluing into the lumen, with epoxy resin (Araldite), a $20 \mathrm{~mm}$ length of $1 \mathrm{~mm}$ bore stainless-steel tubing.

Assay medium was segmented with air and samples were diluted into it. Provision was made for the assay of whole-blood folate extracts (which were carried out satisfactorily by this technique) with a 0.056 inch pump-tube which sampled water continuously during serum assays. The dotted line in Fig. 3 indicates where methaemalbumin was added when necessary. After inoculation the culture was incubated for approximately three hours while passing through a 61 metre long polythene tube with 


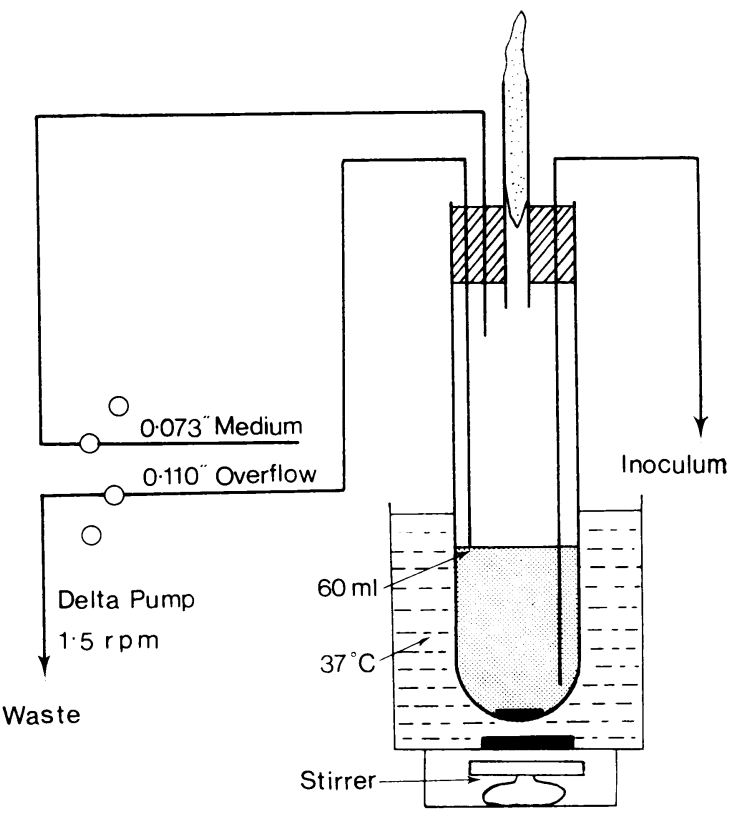

Fig. 2 Diagram of the continuous culture apparatus.

Table 1 Medium for continuous cultures

$46 \mathrm{~g}$ BBL Folic Acid Assay PGA Broth

$75 \mathrm{ml} \mathrm{PteGlu}$ solution (10 $2 \mathrm{~g} / \mathrm{l})$

$0.25 \mathrm{~g}$ ascorbic acid

$5 \mathrm{ml}$ Tween 80 solution $(100 \mathrm{ml} / \mathrm{l})$

$1.0 \mathrm{ml}$ chloramphenicol solution $(10 \mathrm{~g} / 1$ in ethanol)

Make up to 1 litre with water, boil, and cool

a $2 \mathrm{~mm}$ bore (Portex Ltd, Hyde Type PP270). The tube was contained in an incubator as a water-bath proved unsatisfactory (Tennant and Withey, 1974). The pressure gradient along the tube was increased by pumping out both sides of the debubbler at the end of the first stage. A solution of TTC was diluted into the culture after resegmentation with nitrogen, and the incubation was continued for a further hour while the culture was pumped through two $12 \cdot 2$ metre glass coils (Technicon heating bath coils). Nitrogen was supplied from a simple 'gasometer' made by floating a 2 litre measuring cylinder upsidedown in water. The volume of unsegmented culture between the removal of the air bubbles and resegmentation with nitrogen was minimised by using $0.8 \mathrm{~mm}$ bore silicone rubber tubing for connections and by cutting the pump-tube tail as short as possible.

Optical densities $\left(E \begin{array}{c}15 \mathrm{~mm} \\ 500 \mathrm{~nm}\end{array}\right)$ were estimated using

an AutoAnalyzer colorimeter (Technicon) and

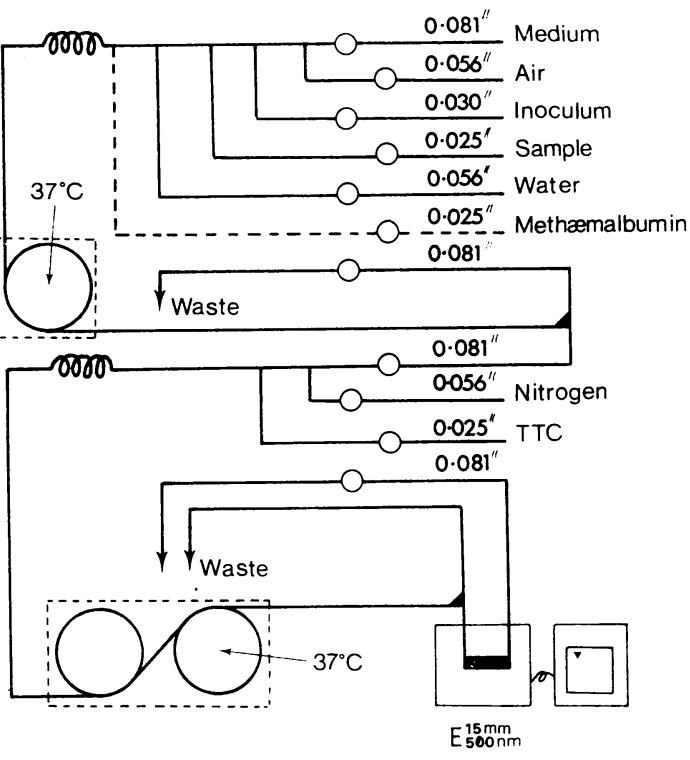

Fig. 3 Flow-diagram of the serum folate assay.

the peaks were recorded with a chart speed of $51 \mathrm{~mm} /$ hour.

SAMPLING CYCLE

A sample to wash ratio of $1: 4$ was used with a cycle time of five minutes. A Technicon Large Sampler (with a turntable capacity of 200 samples) was $\mathbb{D}$ fitted with a $0.2 \mathrm{rpm}$ programmer motor. The probe motor circuit was modified to provide a 15 -second air gap between wash and sample and again in the reverse direction. An additional sub-miniature microswitch (R.S. Components Ltd, 13-17, Epworth Street, London EC2P 2HA) was inserted on the probe motor control cam (Fig. 4a) and wired via a $\dot{0}$ shrouded plug and socket (A. E. Bulgin Ltd, ByePass Road, Barking IG11 0A2 Type P561) to two microswitches located in the programmer (Fig. 4b). The programmer cams were adjusted to give the 을 desired delays. (Technicon Instruments Ltd can $\supset$ supply suitably modified samplers.) The use of an AAII sampler (Technicon) has already been de- $\bar{N}$ scribed (Tennant and Withey, 1974).

\section{ASSAY MEDIUM}

The bulk of the present work was performed using 0 BBL Folic Acid Assay PGA Broth (Becton $_{\infty}$ Dickinson Ltd, Empire Way, Wembley HA9 0PS) with the additions shown in Table 2. Bacto-Folic $\stackrel{?}{?}$ Acid Casei Medium (Difco) and medium prepared 0 in the laboratory (Baker et al., 1959) were also used. 0 ' (Tween 80 included in the Difco medium is in- $\mathbb{D}$ 
A.

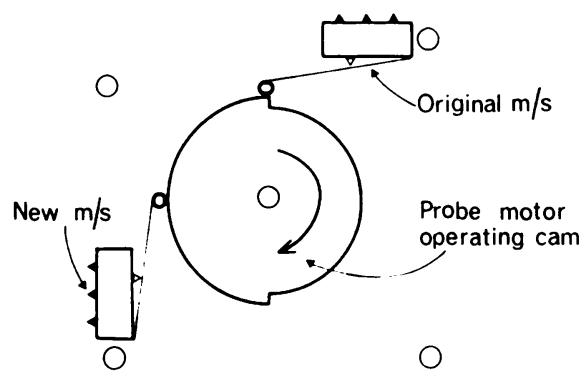

B.

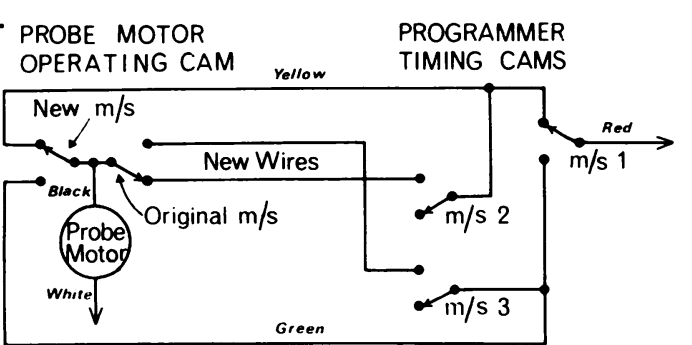

Fig. 4 Modification of the sampler probe-motor circuit to give a delay during the probe movement.

Table 2 Assay medium composition

23.5 g BBL Folic Acid Assay PGA Broth

$100 \mathrm{ml} 1 \mathrm{M} \mathrm{K}_{2} \mathrm{HPO}_{4} / \mathrm{HK}_{2} \mathrm{PO}_{4}$ buffer $(\mathrm{pH} \mathrm{6.35}) *$

$12.5 \mathrm{ml}$ Tween 80 solution $(100 \mathrm{ml} / \mathrm{l})$

$1.0 \mathrm{~g}$ medium supplement (see Table 3 )

$1.0 \mathrm{~g}$ sodium ascorbate

$0.5 \mathrm{ml}$ chloramphenicol solution $(10 \mathrm{~g} / \mathrm{l}$ in ethanol)

Make up to $500 \mathrm{ml}$ with water

* $1 \mathrm{M}$ buffer pH 6.35 $=47.4 \mathrm{~g} \mathrm{~K}_{2} \mathrm{HPO}_{4}+99 \mathrm{~g} \mathrm{KH}_{2} \mathrm{PO}_{4}$ in glass distilled water

Table 3 Assay medium supplement

\begin{tabular}{ll}
\hline Addition & g/l medium \\
\hline S permine 4HCl* & 0.2 \\
L-Glutathione (reduced) $\dagger$ & 0.05 \\
Riboflavin $\dagger$ & 0.0025 \\
Pyridoxine $\mathrm{HCl} \dagger$ & $0 \cdot 1$ \\
L-Cysteine $\ddagger$ & $0 \cdot 5$ \\
Sodium carbonate (anhydrous) $\ddagger$ & $0 \cdot 4$ \\
D-Biotin $\ddagger$ & $0 \cdot 0005$ \\
Guanosine 5-monophosphate (di-sodium salt) $\dagger$ & $0 \cdot 1$ \\
DL-Serine $\dagger$ & $0 \cdot 2$ \\
L-Glutamine $\ddagger$ & 0.5 \\
\hline
\end{tabular}

*Serva (Micro-Bio Laboratories Ltd, Sullivan Road, London SW6 3DX)

+Koch Light Laboratories Ltd, Colnbrook, SL3 OBZ

$\ddagger$ British Drug Houses Ltd, Poole BH12 4NN

sufficient for use in this method and may be ignored.) The growth response showed a positive drift unless the medium supplement (Table 3 ) was added. A dry-mix was stored at $4^{\circ} \mathrm{C}$.
OPERATING PROCEDURE

A dilute Chloros (ICI Ltd) solution $(1 \mathrm{ml} / \mathrm{l})$ was pumped through the tubes for an hour before use each day and also when the machine was not in use. The speed of the pump was adjusted to give a total assay time of 4-4.5 hours (approximately $4 \mathrm{rpm}$ ). Medium was prepared in $500 \mathrm{ml}$ volumes which was sufficient for a 15-18 hour assay. Connections were made to the assay medium, continuous culture, wash-water supply, and TTC solution. Strict aseptic technique was not essential although care was taken to avoid bacterial contamination building up (that is, clean, sterile glassware, freshly distilled water, etc). A stable baseline was established by running the assay for an hour before sampling started. Samples were assayed at two dilutions (neat in the first cup and a $\frac{1}{2}$ dilution in the second). When the baseline appeared on the recorder it was adjusted to about $80 \%$ transmission using an aperture slide drilled with a $4 \mathrm{~mm}$ hole $35 \mathrm{~mm}$ from its lower end. The amount of colour produced in the assay was not critical and could be controlled by altering the TTC concentration. A $1 \mathrm{~g} / 1$ solution was normally used but could be halved or doubled as necessary. The choice of concentration was limited by two factors. If the peaks were too small serum turbidity caused high results. Excess formazan production, on the other hand, caused cells to precipitate and the baseline drifted upwards as they

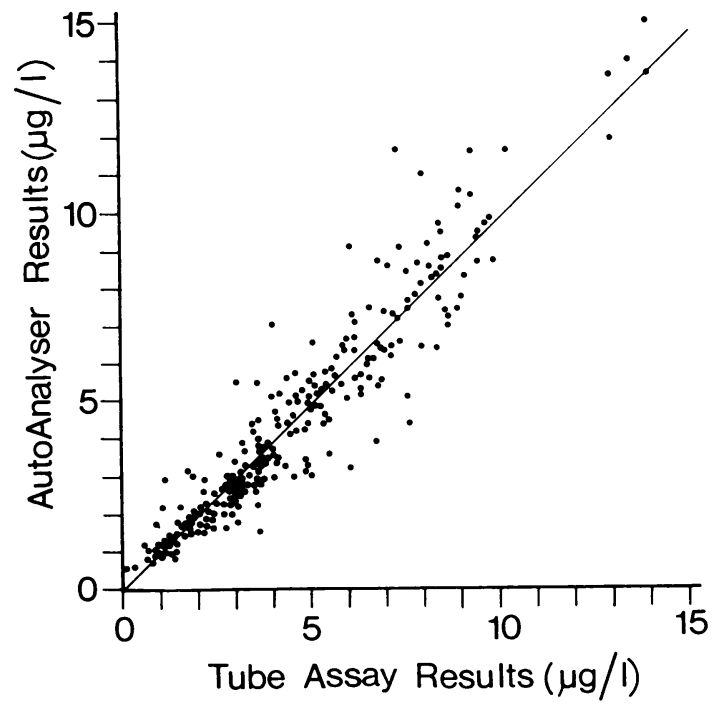

Fig. 5 Comparison of serum folate assay results from 235 sera by the present method with the tube assay. 
accumulated in the flow-cell. Satisfactory results were obtained when $10 \mu \mathrm{g} / \mathrm{l}$ PteGlu solutions resulted in peak absorbance $\left(E_{500 \mathrm{~nm}}^{15 \mathrm{~mm}}\right)$ between $0 \cdot 10$ and $1 \cdot 00$.

The assay was standardised with PteGlu solutions of $0,1,2,4,6,8$, and $10 \mu \mathrm{g} / \mathrm{l}$ prepared fresh daily from a $1 \mathrm{~g} / \mathrm{l}$ stock solution stored at $-20^{\circ} \mathrm{C}$. Standards were included at intervals through the batch and a set of control sera were assayed in each batch.

Five hundred millilitres of medium was sufficient to assay between 30 and 40 sera although the method would handle about 80 samples a day with standards and controls.

\section{TUBE ASSAY}

The tube assay was a modification of that described previously (Tennant and Withey, 1972). The phosphate buffer concentration was reduced to 0.075 м (Tennant et al., 1974) and chloramphenicol $(10 \mathrm{mg} / \mathrm{l})$ was added as a solution in ethanol.

\section{Results}

COMPARISON WITH THE TUBE ASSAY

The folate concentrations of 235 samples assayed using BBL medium in the present method $(y)$ were compared with the results from the tube assay $(\mathrm{x})$ (Fig. 5). The correlation coefficient (r) was 0.939 and the regression equation was $\mathrm{y}=0.98 \mathrm{x}-0.03$. Similar results were obtained using Difco medium $(\mathrm{N}=83 ; \mathrm{r}=0.942 ; \mathrm{y}=0.87 \mathrm{x}+0.49)$ and medium prepared in the laboratory $(\mathrm{N}=68 ; \mathrm{r}=0.949$; $y=0.99 x+0.11)$.
ASCORBATE ADDITION TO SERUM SAMPLES

Routine samples did not contain ascorbate. When 은 ascorbate was added $(0.05 \mathrm{ml}$ of ascorbic acid $\overrightarrow{\vec{D}}$ solution $(100 \mathrm{~g} / \mathrm{l})$ per millilitre of serum) to sera as they were separated (and at an equivalent concentration to the standard PteGlu solutions) the correlation of the assay results was similar to that shown in Fig. $5(\mathrm{~N}=125 ; \mathrm{r}=0.923 ; \mathrm{y}=0.92 \mathrm{x}+0.05)$.

Sera were stored for 2.5 years at $-20^{\circ} \mathrm{C}$ without added ascorbate and assayed by the present method. $\overrightarrow{0}$ Results were compared with tube assay results obtained when the samples were fresh $(\mathrm{N}=48$; $r=0.940 ; y=0.85 x+0.38)$.

\section{REPRODUCIBILITY}

One of three control sera was assayed approximately 20 times by the present method and by the tube assay on the same day. The aliquots of the control $\infty$ serum were spread through the batches, alternating $ᄋ$ with routine samples. Each control serum was $\rightarrow$ assayed in 10 batches over a two-month period. The results (Table 4) show that the overall coefficient of variation within the batch was $7 \cdot 6 \%$ by the present method and $6.4 \%$ by the tube assay. Variation between the batches was assessed by comparison of the mean values of each batch and showed tha@ overall, the coefficient of variation with the aute mated method was $8.2 \%$ compared with 14.46 with the tube assay.

\section{RECOVERY EXPERIMENTS}

PteGlu was added to sera with known folate concentrations and the total folate measured was compared with that expected (Table 5). The mean recovery was $102 \%$.

Table 4 Comparison of reproducibility

\begin{tabular}{|c|c|c|c|c|c|c|c|c|c|c|c|c|c|c|c|c|c|c|}
\hline & \multicolumn{6}{|c|}{ Cortrol $A$} & \multicolumn{6}{|c|}{ Control B } & \multicolumn{6}{|c|}{ Control $C$} \\
\hline & \multicolumn{3}{|c|}{ Tube method } & \multicolumn{3}{|c|}{ AutoAnalyzer } & \multicolumn{3}{|c|}{ Tube method } & \multicolumn{3}{|c|}{ AutoAnalyzer } & \multicolumn{3}{|c|}{ Tube method } & \multicolumn{3}{|c|}{ AutoAnalyzer } \\
\hline & $N$ & Mean & $c v$ & $N$ & Mean & $c v$ & $N$ & Mean & $c v$ & $N$ & Mean & $c v$ & $N$ & Mean & $c v$ & $N$ & Mean & $\mathrm{Cv}$ \\
\hline & 28 & $1 \cdot 7$ & $6 \cdot 8$ & 21 & $1 \cdot 5$ & $9 \cdot 2$ & 22 & $1 \cdot 7$ & $8 \cdot 1$ & 17 & $2 \cdot 1$ & $6 \cdot 7$ & 18 & $7 \cdot 0$ & $10 \cdot 7$ & 17 & $6 \cdot 8$ & $5 \cdot 2$ \\
\hline & 23 & $1 \cdot 7$ & $5 \cdot 9$ & 21 & $1 \cdot 5$ & $7 \cdot 3$ & 32 & $1 \cdot 8$ & $2 \cdot 6$ & 13 & $2 \cdot 2$ & $8 \cdot 4$ & 34 & $8 \cdot 1$ & $10 \cdot 8$ & 23 & $7 \cdot 8$ & $3 \cdot 3$ \\
\hline Mean serum folate & 36 & $1 \cdot 5$ & $4 \cdot 0$ & 19 & $1 \cdot 6$ & $6 \cdot 0$ & 34 & 1.9 & $9 \cdot 0$ & 12 & $2 \cdot 2$ & $7 \cdot 1$ & 24 & $8 \cdot 7$ & $5 \cdot 4$ & 24 & $7 \cdot 6$ & $2 \cdot 5$ \\
\hline$(\mu \mathrm{g} / 1)$ & 34 & $2 \cdot 2$ & $2 \cdot 9$ & 27 & $1 \cdot 8$ & $8 \cdot 3$ & 32 & $2 \cdot 1$ & $4 \cdot 6$ & 20 & $2 \cdot 2$ & $8 \cdot 7$ & 36 & $8 \cdot 3$ & $5 \cdot 1$ & 26 & $7 \cdot 1$ & 11.6 \\
\hline & 16 & $1 \cdot 1$ & $3 \cdot 2$ & 21 & $1 \cdot 3$ & 9.9 & 22 & $2 \cdot 1$ & $6 \cdot 5$ & 31 & $2 \cdot 5$ & $6 \cdot 6$ & 16 & $7 \cdot 2$ & $7 \cdot 8$ & 25 & $6 \cdot 6$ & 4.4 \\
\hline $\begin{array}{l}\operatorname{cv}(\%)= \\
\operatorname{SD} \times 100\end{array}$ & 22 & $1 \cdot 5$ & $3 \cdot 7$ & 21 & $1 \cdot 5$ & $9 \cdot 0$ & 22 & $2 \cdot 1$ & $3 \cdot 0$ & 22 & $2 \cdot 4$ & $8 \cdot 1$ & 22 & $9 \cdot 3$ & $2 \cdot 6$ & 27 & $7 \cdot 6$ & $5 \cdot 6$ \\
\hline \multirow[t]{4}{*}{ Mean } & 36 & $1 \cdot 5$ & $6 \cdot 2$ & 22 & $1 \cdot 5$ & $9 \cdot 7$ & 20 & $2 \cdot 1$ & $3 \cdot 0$ & 23 & $2 \cdot 0$ & $7 \cdot 1$ & 24 & 6.9 & $7 \cdot 7$ & 23 & $7 \cdot 2$ & $10 \cdot 1$ \\
\hline & 29 & 1.9 & $7 \cdot 1$ & 29 & $1 \cdot 4$ & $10 \cdot 8$ & 27 & $1 \cdot 8$ & $9 \cdot 2$ & 17 & $2 \cdot 0$ & 6.0 & 18 & $6 \cdot 4$ & $18 \cdot 8$ & 22 & $7 \cdot 7$ & 10.4 \\
\hline & 20 & $1 \cdot 3$ & $5 \cdot 6$ & 21 & $1 \cdot 2$ & 8.6 & 22 & $2 \cdot 2$ & $5 \cdot 5$ & 16 & $2 \cdot 3$ & $5 \cdot 0$ & 35 & 8.9 & $8 \cdot 8$ & 27 & $6 \cdot 8$ & $7 \cdot 8$ \\
\hline & 32 & $1 \cdot 1$ & 2.9 & 22 & 1.4 & 8.9 & 34 & $2 \cdot 0$ & $5 \cdot 8$ & 26 & $2 \cdot 1$ & $6 \cdot 3$ & 17 & $7 \cdot 4$ & $9 \cdot 4$ & 30 & $6 \cdot 8$ & $8 \cdot 8$ \\
\hline $\begin{array}{l}\text { Overall mean and } \\
\text { mean } \mathrm{cv}\end{array}$ & & $1 \cdot 6$ & $4 \cdot 8$ & & $1 \cdot 5$ & $8 \cdot 8$ & & $2 \cdot 0$ & $5 \cdot 7$ & & $2 \cdot 0$ & $7 \cdot 0$ & & $7 \cdot 8$ & $8 \cdot 7$ & & $7 \cdot 2$ & $7 \cdot 0$ \\
\hline $\begin{array}{l}\text { cv betwe en means of } \\
\text { each batch }(\%)\end{array}$ & & $22 \cdot 2$ & & & $10 \cdot 9$ & & & $8 \cdot 5$ & & & $7 \cdot 4$ & & & $12 \cdot 5$ & & & $6 \cdot 2$ & \\
\hline
\end{tabular}


Table 5 Assay recovery

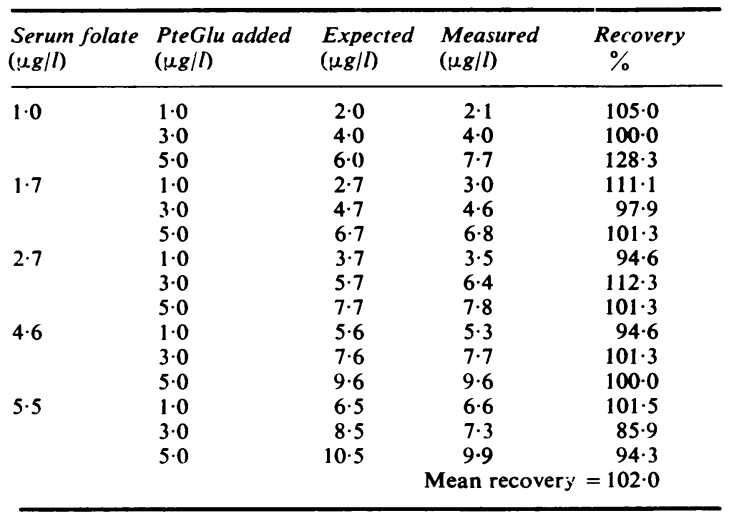

\section{EFFECT OF INHIBITORS}

It was noticed that many sera which needed prior dilution in order to give parallel results in the tube assay gave the correct results with the present method when sampled without prior dilution. Typical examples of antibacterial drugs, together with some other drugs known to affect $L$. casei growth, were added to serum, and the apparent folate concentrations when assayed by the automated method compared with the results from the tube assay (Table 6). The sensitivity of $L$. casei to the drugs was lower in the present method than in the tube assay. The decreased sensitivity to benzyl penicillin was particularly striking.

Some sera showed inhibitory effects in the present method when there was no corresponding loss of parallelism in the tube assay. Investigation showed that this was with sera from patients showing intravascular haemolysis. Peak height was little affected but the baseline was lowered. This was due to the presence of methaemalbumin. When a solution of methaemalbumin was sampled continuously in parallel with the serum sample-line (Fig. 3) sera from patients with intravascular haemolysis had no effect on the baseline. The concentration of methaemalbumin solutions was indexed by measuring the change in absorbance $\left(\mathrm{E}_{558 \mathrm{~mm}}^{10 \mathrm{~mm}}\right)$, due to the $a$ band of albumin haemachromogen, during Schumm's test (Varley, 1962). The index had to be greater than 1.20 to prevent inhibition by samples. A suitable solution was obtained by mixing $5 \mathrm{ml}$ of haematin solution (containing $13 \mathrm{mg}$ haematin and $100 \mathrm{mg}$ of $\mathrm{KOH}$ ) with $100 \mathrm{ml}$ of a $5 \mathrm{~g} / \mathrm{l}$ solution of albumin (Armour Pharmaceutical Co Ltd, Eastbourne BN22 9AG). There was no effect on the parallelism of the assay although the rate of TTC reduction was reduced. In routine use there was no need to sample continuously a methaemalbumin solution. As the peak height was affected very much less than the baseline it was possible to measure the 'peak' absorbance with the log-scale ruler from the recorder and thus make a comparison with the standard curve.

\section{Discussion}

The method described here has proved robust and reliable, producing results which compare favourably with those from the routine tube assay. Variation within the batch was little different from that of the tube assay. The variation between batches was lower with the automated method,

Table 6 Typical effect of inhibitory drugs on the serum folate results produced by the tube assay and by the automated method

\begin{tabular}{|c|c|c|c|}
\hline \multirow[t]{2}{*}{ Drug } & \multicolumn{2}{|c|}{$\begin{array}{l}\text { Serum drug concentration which reduced apparent serum folate } \\
\text { by } 10 \%\end{array}$} & \multirow[t]{2}{*}{$\begin{array}{l}\text { Serum drug concentration } \\
\text { during therapy }\end{array}$} \\
\hline & Tube & Automated & \\
\hline $\begin{array}{l}\text { Benzyl penicillin } \\
\text { Cephaloridin } \\
\text { Chloramphenicol } \\
\text { Colistin sulphometholate } \\
\text { Gentamicin } \\
\text { Methotrexate } \\
\text { Pyrimethamine } \\
\text { Streptomycin } \\
\text { Sulphadimidine } \\
\text { Tetracycline } \\
\text { Trimethoprim (as septrin) }\end{array}$ & $\begin{array}{l}1.2 \mathrm{mg} / 1 \\
33 \mathrm{mg} / \mathrm{l} \\
490 \mathrm{mg} / 1 \\
>4000 \mathrm{mg} / \\
75 \mathrm{mg} / 1 \\
0.18 \mu \mathrm{rg} / 1 \\
0.91 \mathrm{mg} / 1 \\
180 \mathrm{mg} / 1 \\
>3300 \mathrm{mg} / 1 \\
2.1 \mathrm{mg} / 1 \\
0.46 \mathrm{mg} / 1\end{array}$ & $\begin{array}{l}36 \mathrm{mg} / 1 \\
71 \mathrm{mg} / \mathrm{l} \\
760 \mathrm{mg} / \mathrm{l} \\
>4000 \mathrm{mg} / 1 \\
340 \mathrm{mg} / \mathrm{l} \\
1.6 \mathrm{\mu g} / \mathrm{l} \\
1.3 \mathrm{mg} / \mathrm{l} \\
310 \mathrm{mg} / 1 \\
>3300 \mathrm{mg} / 1 \\
5.0 \mathrm{mg} / 1 \\
3.7 \mathrm{mg} / \mathrm{l}\end{array}$ & $\begin{array}{l}1 \cdot 2-12 \mathrm{mg} / \mathrm{l}^{*} \\
0 \cdot 2-30 \mathrm{mg} / \mathrm{l}^{*} \\
4-10 \mathrm{mg} / 1^{*} \\
0 \cdot 1-8 \mathrm{mg} / \mathrm{l}^{*} \\
1-7 \mathrm{mg} / 1^{*} \\
200-700 \mu \mathrm{gg} / 1^{\dagger} \\
0 \cdot 1-0.6 \mathrm{mg} / 1^{\ddagger} \\
7-50 \mathrm{mg} / 1^{*} \\
17-82 \mathrm{mg} / 1^{*} \\
1-30 \mathrm{mg} / 1^{*} \\
1.6-3.5 \mathrm{mg} / 1 \S\end{array}$ \\
\hline
\end{tabular}

* Martindale (1972)

+Freeman-Narrod et al. (1975)

†Smith and Ihrig (1959)

§Fowle (1973) 
reflecting the constant physiological state of the inoculum grown in continuous culture.

The introduction of a different strain of L. casei (NCIB 11295) should cause no problem in the comparison of results with other laboratories as chloramphenicol-resistant forms of the parent strain (NCTC 10302) compared well with NCIB 10463 (Tennant et al., 1974) which is now in widespread use.

This method offers advantages over the tube assay in relation to glassware preparation, inocula production, and working space required. Of considerable practical value is the reduced sensitivity of the method to growth-inhibiting drugs. However, the most significant advantage must be in the reduced technician time necessary to prepare the assay. All that is then required is intermittent attention to check its operation and to add samples as they arrive in the laboratory.

I am grateful for the continued interest and encouragement of Dr J. L. Withey during the development of this method.

\section{References}

Anderson, B. B., and Cowan, J. D. (1968). Effect of light on the Lactobacillus casei microbiological assay. Journal of Clinical Pathology, 21, 85-87.

Baker, H., Herbert, V., Frank, O., Pasher, I., Hutner, S. H., Wasserman, L. R., and Sobotka, H. (1959). A microbiologic method for detecting folic acid deficiency in man. Clinical Chemistry, 5, 275-280.

Berg, T. M., Den Berger, J. M., and Behagel, H. A. (1975). Semi-automated method for microbiological vitamin and antibiotic assays. In Some Methods for Microbiological Assay (Society of Applied Bacteriology Technical Series, no. 8), edited by R. G. Board and D. W. Lovelock, pp. 1-22. Academic Press, London.

Butt, E. M., Bonynge, C. W., and Joyce, R. L. (1936). The demonstration of capsules about hemolytic streptococci with India ink or Azo blue. Journal of Infectious Biseases, 58, 5-9.

Davis, R. E., Nicol, D. J., and Kelly, A. (1970). An automated method for the measurement of folate activity. Journal of Clinical Pathology, 23, 47-53.

Fowle, A. S. E. (1973). Aspects of the pharmacokinetic behaviour of trimethoprim and sulphamethoxazole. In Trimethoprim/Sulphamethoxazole in Bacterial Infections, edited by L. S. Bernstein and A. J. Slater, pp. 63-72. Churchill Livingstone, Edinburgh and London.

Freeman-Narrod, M., Gerstley, B. J., Engstrom, P. F., and Bornstein, R. S. (1975). Comparison of serum concentrations of methotrexate after various routes of administration. Cancer, 36, 1619-1624.

Harper, T. A. (1965). A modified 'aseptic addition' assay procedure for the measurement of serum 'folic acid' activity. Nature (London), 207, 947-949.

Herbert, D., Elsworth, R., and Telling, R. C. (1956). The continuous culture of bacteria: a theoretical and experimental study. Journal of General Microbiology, 14, 601-622.

Herbert, V. (1964). Studies of folate deficiency in man. Proceedings of the Royal Society of Medicine, 57, 377-384.

Herbert, V. (1966). Aseptic addition method for Lactobacillus casei assay of folate activity in human serum. Journal of Clinical Pathology, 19, 12-16.

Martindale, W. (1972). The Extra Pharmacopeia, 26th edition, edited by N. W. Blacow and A. Wade. Pharmaceutical Press, London.

Millbank, L., Davis, R. E., Rawlins, M., and Waters, A. H. (1970). Automation of the assay of folate in serum and whole blood. Journal of Clinical Pathology, 23, 54-59.

Shaw, W. H. C., and Duncombe, R. E. (1963). The continuous automatic microbiological assay of anti biotics. The Analyst, 88, 694-701.

Slade, B. A., Harrison, J. W., and Shaw, W. (1974) Effect of incubation time on folate values. Americañ Journal of Clinical Pathology, 61, 74-77.

Smith, C. C., and Ihrig, J. (1959). Persistent excretion of pyrimethamine following oral administration. American Journal of Tropical Medicine and Hygiene, 8, 60-62.

Tennant, G. B., Newberry, C. H., Davies, J., and Dziedzic, H. (1974). A comparison of seven strains of Lactobacillus casei var. rhamnosus in relation to their use in the microbiological assay of serum folate. Journal of Applied Bacteriology, 37, 373-389.

Tennant, G. B., and Withey, J. L. (1972). An assessment of work simplified procedures for the microbiological assay of serum vitamin $\mathrm{B}_{12}$ and serum folate. Medical Laboratory Technology, 29, 171-181.

Tennant, G. B., and Withey, J. L. (1974). Preliminary report of a fully automated six-hour folate assay using Lactobacillus casei. In Automation in Analytical Chemistry (London Symposium 1971), pp. 440-449 Technicon, Basingstoke.

Varley, H. (1962). Practical Clinical Biochemistry, 3rd edition, pp. 492-493. Heinemann, London.

Waters, A. H., and Mollin, D. L. (1961). Studies on the folic acid activity of human serum. Journal of Clinical Pathology, 14, 335-344. 